\title{
Opinions of Pre-Service Classroom Teachers about Academic Controversy Method
}

\author{
Aşkın Baydar ${ }^{1}$ \\ ${ }^{1}$ Faculty of Education, Artvin Çoruh University, Artvin, Turkey \\ Correspondence: Aşkın Baydar, Faculty of Education, Artvin Çoruh University, Artvin, Turkey. Tel: \\ 90-466-215-1000. E-mail: askinbaydar@ artvin.edu.tr
}

Received: October 10, 2020

Accepted: December 12, 2020

Online Published: December 18, 2020

doi:10.5539/hes.v11n1p55

URL: https://doi.org/10.5539/hes.v11n1p55

\begin{abstract}
The aim of this study is to determine the opinions of pre-service classroom teachers about academic controversy, from the cooperative learning methods, implemented in social studies teaching course. Using the action research pattern from the qualitative research approaches, the study group for the research comprised 42 preservice teachers in third year attending the primary education department in a state university. Research data were collected from preservice teachers with an interview form asking open-ended questions Responses of preservice teachers to the questions included opinions about the positive and negative aspects of the academic controversy method; whether they would apply this method in future classes and why; and about the contribution of the method to social and individual development of students. Opinions of preservice teachers after implementing the method in the class environment were that the academic controversy method was fun and beneficial for peer teaching; increased in-class interaction, retention of knowledge and self-confidence; ensured effective participation in class, active learning and conflict management; provided democracy education, directed research, taught respect for differences, provided a multidimensional perspective, and reduced the need for authority; and that it developed self-control, self-expression, decision-making and problem-solving skills. Additionally, criticisms mentioned by preservice teachers included causing noise in the classroom, not being appropriate for all class levels, lessons or topics, being difficult to implement in crowded classrooms and that the duration was not sufficient for the implementation.
\end{abstract}

Keywords: academic controversy, teacher education, classroom teaching, social studies teaching

\section{Introduction}

Cooperative learning is a learning activity where socially structured information exchange occurs within groups of learners, where group individuals are responsible for their own learning and motivate other group members (Olsen \& Kagan, 1992). With this method, students learn what they cannot learn alone or in a competitive system (Johnson, Johnson, \& Holubec, 1986). There are five basic elements to cooperative learning. These are positive interdependence where workers within a group have the perception that they are dependent on each other for success. Each group member works for the success of others (Johnson \& Johnson, 1991). Face-to-face promotive interaction involves sharing resources while working within the group, verbally encouraging each other's efforts, explaining topics which friends don't understand, solving each other's problems, reminding of previous information and assisting with topics like transferring information (Johnson, D. W., Johnson, R. T., \& Holubec, E. J., 1994). Individual accountability means that each individual in the group is held responsible for working their share by other group members. This is required for the success of the whole group. Every individual is responsible for their own learning for the success of the group (Johnson, Johnson, \& Smith, 1991). Social competencies encompass abilities like leadership, decision-making and communication required when individuals work in groups (Johnson \& Johnson, 1994). The final element of cooperative learning is group processing and involves group members assessing each member, and deciding how beneficial or not the actions taken were after a certain stage during group work (Johnson et al., 1991).

The cooperative learning method of academic controversy is a method which has been the topic of less research compared to methods like combination, the teams-games-tournaments, and student teams achievement divisions. In the method developed by Johnson and Johnson (1979), students are divided into groups of four. As in other cooperative methods, these groups are created in heterogeneous form by noting achievement level, gender and 
areas of interest. Then each group divides into two. Each pair within the group takes a side on a controversial topic. They collect information about the topic to be discussed; this information is shared with the other pair along with their own opinions. Each pair prepares a presentation presenting the opposite view and presents it. When presenting, contrasting opinions should be carefully listened to and notes taken. After presentations, the pairs within the group change roles and must defend the view of the opposite group and repeat the process. Finally, every group finds a common role in the controversial topic to reach consensus, the group prepares a report and presents to the whole class (Johnson et al., 1991).

Research at primary and middle education level about the effect of academic controversy in learning environments concluded that the method had positive effects on attitude toward science, anxiety about science and problem-solving perception according to Pedersen (1990), social problem-solving skills according to Göğebakan-Yıldız (2015), on self-expression, empathy, listening and conflict resolution skills according to Sarı (2005), speaking skills and reducing speaking anxiety according to Tüzemen and Kardaş (2017) and motivated and encouraged interest in lessons, participation in lessons, self-confidence and enthusiasm for research. Additionally, Pedersen (1990), Güven (2007), Santiloca (2015) and Genç and Şahin (2015) found the method increased academic achievement. Research about participants at university level concluded the academic controversy method had positive effects on topics like multiple perspective thinking, logical discussion, reaching consensus, and knowledge and attitudes about contentious issues (Pederson, 1990), academic achievement (Beilby, 1997), responsibility, interest in lessons, ability to assess their own thoughts, respect for other opinions (Monhardt \& Monhardt, 2000), and looking from different perspectives, critical thinking, listening and compromise skills (Bruen et al., 2016). Kardaş (2015) concluded the academic controversy method had positive effects on the Turkish speaking ability of pre-service Turkish teachers; Khourey-Bowers (2006) found it increased the democratic pedagogic implementation and respect for differences of pre-service teachers; Keçeci (2017) found it affected the biotechnology information levels of pre-service science teachers; and Kırbağ-Zengin, Alan and Keçeci (2016) again found positive effects on content knowledge and science self-efficacy of pre-service science teachers. The aim of this research is to determine the opinions of pre-service classroom teachers about the academic controversy method.

\section{Method}

In this research, the action research pattern was chosen with the aim of receiving opinions of pre-service classroom teachers related to the applicability of the academic controversy method, determining problems encountered during implementation and producing solutions to these problems (Yıldırım \& Şimşek, 2011).

\subsection{Study Group}

A total of 42 students attending the Faculty of Education, Primary Education Department of a state university in the 2018-2019 academic year participated in the study.

\subsection{Data Collection Tools}

The research collected data with an interview form containing four open-ended questions. With the aim of ensuring scope and opinion validity, opinions were received from three academics specializing in the field in the Artvin Çoruh University Department of Educational Sciences. With the aim of ensuring reliability of the research, coded data were given back to four randomly-chosen participants. "The most useful method to increase reliability of qualitative research is member control. In this method, researchers give their notes to participants and participants confirm the records are accurate and complete" (Büyüköztürk, Kılıç Çakmak, Akgün, Karadeniz, \& Demirel, 2012: 245).

\subsection{Analysis of Data}

Participants were given 40 minutes to complete the interview forms. The open-ended questions were used to form an upper theme, and example statements in the responses of each participant were underlined, coded and subthemes were created with frequency values given in tables. In the stage of data analysis, direct quotations were taken from participant statements. Codes like S1, S2, etc. were used instead of the real names of participants.

\subsubsection{Procedure}

The academic controversy method was implemented in the social studies teaching lesson for five weeks. One week before the first lesson where the method was to be implemented, participants were firstly divided into groups of four and then into groups of two within each group. The whole class was given a topic to discuss in the lesson the following week and were requested to prepare references to be used in the discussion in the following lesson. Participants attending and prepared for the lesson prepared a report in the paired groups about the 
controversial topic and presented the report to the opposite group. When presentations were finished, the pairs within the groups exchanged roles and this time prepared a report defending the opposite view and presented it. At the end of the lesson, groups compromised by finding a common route in relation to the controversial topic, prepared a report and presented it to the class.

\section{Results}

In this section, frequency values for the subthemes about the applicability of the academic controversy method among participant opinions were tabulated and direct quotations are given from coded participants.

Table 1. Participant opinions about the first interview question

\begin{tabular}{ll}
\hline Statements & $\mathrm{f}$ \\
\hline Beneficial for peer teaching & 2 \\
Increased in-class interaction & 8 \\
It was fun & 3 \\
Ensured effective participation & 15 \\
Ensured active learning & 8 \\
Provided democratic education & 1 \\
Directed research & 1 \\
Taught respect for those who are different & 15 \\
Provided multiple perspectives & 17 \\
Provided self-confidence & 17 \\
Increased retention of knowledge & 16 \\
Reduced the need for authority & 2 \\
Ensured conflict management & 1 \\
\hline
\end{tabular}

Table 1 presents the responses of participants to the first research question of "what are your positive opinions about the academic controversy method?"

Subthemes and example participant statements are listed below:

"Beneficial for peer teaching"

S8: information was acquired mutually, they learned from each other.

"Increased in-class interaction"

S3: It increased socialization in class.

S9: Due to controversial topics, our interaction with our friends increased. This made it easier to understand each other.

S33: Choosing different individuals when creating the groups brings the students closer together.

"It was fun"

S4: It made lessons more fun, it attracted students' attention to the lessons better.

"Ensured effective participation"

S5: It was a technique ensuring everyone participated more effectively in the lesson.

S20: Not every student may be close to all their friends in class. This method brings students together in a discussion environment and will ensure they socialize.

S37: It ensures that even students who are not interested and don't participate in lessons, participate in class.

"Ensured active learning"

S23: It made learning easier because information was both read and shared. When discussion is involved, it fully cemented what we learned.

S24: As students construct their own knowledge with this method, they will learn the information more easily.

Provided democratic education

S6: It trains respectful and democratic individuals.

Directed research

S29: It may direct people toward research. 
Taught respect for those who are different

S7: Students learn to be respectful when faced with different opinions.

Provided multiple perspectives

S2: It shows that one problem does not have a single solution.

S6: It provides the opportunity for students to look at a topic from different aspects.

S7: They realize a problem does not have a single solution path or answer. It ensures they look at events from different perspectives.

S13: They learned a problem had a variety of solution paths.

S14: It contributed to us gaining different perspectives about different aspects of topics.

S23: It assisted positive thinking.

S36: Group members learn different opinions in order to defend different aspects of the topic.

S38: It ensured we dealt with different dimensions of an event, situation or topic.

S41: Different aspects of a topic were dealt with as there are different opinions and perspectives about a topic.

Provided self-confidence

S1: It developed a student's feeling of self-confidence in order to comfortably speak their thoughts or explain themselves.

S40: For example, you can learn the thoughts of a student who doesn't talk much by making them talk with this method.

Increased retention of knowledge

S2: Because people have discussed a topic in the school environment, they will internalize that topic better.

S6: It ensures permanency of learning as students have to speak about what they learned and transform it into practice.

Reduced the need for authority

S3: They learned by discussing themselves.

S26: I don't think they will need teachers to learn information after a certain age.

Table 2. Participant opinions about second interview question

\begin{tabular}{ll}
\hline Statements & f \\
\hline Deviating from the topic & 6 \\
Noisy, confusing & 10 \\
Caused conflict & 11 \\
Conflict management was difficult & 1 \\
Not suitable for all levels & 3 \\
Not suitable for all lessons & 2 \\
Not suitable for all topics & 5 \\
Difficult in crowded classrooms & 5 \\
Insufficient duration & 7 \\
Focus only on topic of responsibility & 2 \\
Not able to hear the class & 1 \\
Loss of self-confidence & 4 \\
\hline
\end{tabular}

Table 2 provides the responses of participants to the second question in the research of "what are your negative opinions about the academic controversy method?"

Subthemes are participant statements are given below:

Deviating from the topic

S3: If the teacher doesn't control things, talk may deviate from the topic and become chat.

S6: The teacher needs to draw the boundaries of the topic well. Or else they may deviate from the topic.

Noisy, confusing 
S13: It is very difficult to ensure silence in the class.

Caused conflict

S1: For there to be no friction, it is necessary for the teacher to organize things well.

S2: It is a possibility that the topic discussed could be personalized, that may create a negative effect.

S3: It causes conflict to be experienced within the group. For example, there may be a very hard reaction to an example someone gives, if there is not acceptance, it may cause friction within the group.

S16: Students may become polarized, they may conflict with each other, they may develop prejudice against each other.

S17: It is solid, hard and unmerciful. It is not about learning new things, it's about not thinking of anything other than your own idea and not being moderate.

S39: It's definitely not a suitable method for students who get annoyed and angry easily.

S42: It makes class management hard.

Not suitable for all levels

S21: I wouldn't use it at primary level, but I would use it for university or high school.

S22: I would use it for $7^{\text {th }}$ and $8^{\text {th }}$ class students.

Difficult in crowded classrooms

S6: It is difficult to apply in crowded classrooms, so it must be controlled well. Every student may not participate in the work equally.

S27: There may be problems with controlling the class.

S36: It is necessary for us to be sure that everyone within the group is really participating in the work.

Insufficient duration

S29: It requires a long duration.

Focus only on topic of responsibility

S15: As we feverishly defend our own topic, we don't focus much on other topics.

D39: It is difficult to keep discussions on topic. They may deviate from the target. There may be problems sometimes with class discipline.

Not able to hear the class

S38: One of the negative aspects of the method is not being able to hear ideas in the whole class.

Loss of self-confidence

S11: If there is a discussion environment which will make the student feel bad in the activity, I don't think that student will participate in that lesson again.

S24: In paired groups some students may express their opinions and apply pressure to their friends and prevent them from speaking their opinions. While some students want to speak, some are shy so the desired environment may not be created.

Table 3. Participant opinions about third interview question

\begin{tabular}{ll}
\hline Statements & $\mathrm{f}$ \\
\hline Yes, I will use topics involving contrasts & 2 \\
Yes, I will use topics open to interpretation & 2 \\
Yes, I will use development contribution & 12 \\
Yes, it will ensure I know the students & 1 \\
Yes, it will ensure active learning & 7 \\
Yes, it will provide a different perspective & 4 \\
No, it will cause conflict & 6 \\
No, class management will be difficult & 5 \\
No, there will be no real compromise & 3 \\
\hline
\end{tabular}

Table 3 gives the responses of participants to the third interview question in the research of "when you start 
working, will you use this method? Why?"

Subthemes and example participant statements are given below:

Yes, I will use topics involving contrasts

S2: There are many subtopics and contrasts, for example when explaining forms of governance I think I will use it well for topics like monarchy, theocracy, and democracy.

Yes, I will use topics open to interpretation

S34: I will use it for topics requiring interpretation.

Yes, I will use development contribution

S3: With this method, many values and skills can be applied at the same time and in a very short period and it can be used to acquire these permanently.

Yes, it will ensure I know the students

S5: I will allow me to know the students better from different aspects.

Yes, it will ensure active learning

S6: Because there will be a student-centered class environment.

Yes, it will provide a different perspective

S8: I will use it because I think with this method students do not just develop themselves but also other people in the lives outside school.

No, it will cause conflict

S16: It's not a good method because it polarizes students.

No, class management will be difficult

S23: I won't use it because it will be difficult to control students and there will be time problems.

No, there will be no real compromise

S29: I won't use it because there is compromise in the compromise stage in the groups because the rule requires it, I don't think it provides real compromise.

Table 4. Participant opinions about fourth interview question

\begin{tabular}{ll}
\hline Statements & $\mathrm{f}$ \\
\hline Ensures socialization & 14 \\
Develops feeling of belongingness & 2 \\
Teaches leadership & 1 \\
Teachers responsibility & 2 \\
Develops design of academic self & 1 \\
Develops self-expression skills & 23 \\
Develops self-regulation skills & 4 \\
Develops thinking skills & 5 \\
Develops creativity & 3 \\
Develops empathy skills & 3 \\
Develops criticism skills & 7 \\
Develops communication skills & 14 \\
Develops listening skills & 7 \\
Develops speaking skills & 2 \\
Develops interpretation skills & 2 \\
Develops questioning skills & 4 \\
Develops decision-making skills & 1 \\
Develops comprehension skills & 1 \\
Develops problem-solving skills & 1 \\
\hline
\end{tabular}

Table 4 presents the answers participants gave to the fourth interview question in the research "how do you assess the method in terms of effects on individual and social development?" 
Subthemes and example participant statements are given below:

Ensures socialization

S7: It's a very effective method in terms of socialization.

Develops feeling of belongingness

S6: It develops the student's feelings of belonging to the group and secureness.

S36: The student will feel they are part of the group and will fulfill their duties to the group.

Teaches leadership

S7: It ensures leadership qualities are revealed.

Teacher's responsibility

S21: It provides a certain level of responsibility.

S22: It develops awareness of taking responsibility as they have a duty to complete tasks given within the group.

Develops design of academic self

S5: It develops academic beliefs about self-learning.

Develops self-expression skills

S1: It offers students an environment where they can reflect their own thoughts.

S9: ... because different people come together it will teach sharing feelings and thoughts.

S13: They gain the habit of openly speaking and defending what they know and think in society.

S30: Being able to speak openly is good in terms of overcoming shyness, I think it has positive effects.

S34: The student learns to defend themselves against other individuals. It develops speaking abilities.

Develops self-regulation skills

S3: They see the inadequacies and differences in their own thinking.

S17: It provides the opportunity to know themselves.

S24: It strengthens skills about being able to control time.

S25: I think it allows the person to know themselves as an individual.

S34: People observe their own development.

Develops thinking skills

S7: It will be very efficient in terms of developing our students' thinking skills.

S39: They acquire upper-level thinking skills like interpretation, analysis, synthesis and assessment.

Develops creativity

S19: It may reveal new ideas when preparing group reports.

Develops empathy skills

S13: It's effective in being tolerant and gaining skills to analyze the causes and reasoning of the opposite side.

Develops criticism skills

S11: We can say it's the best method I will use to develop critical thinking skills.

Develops communication skills

S19: Listening to the opposite group's ideas will positively contribute to development of communication skills.

S24: Strengthens communication skills.

S29: There is more comfortable communication with those around them.

S33: It allows regular behavior like speaking in turn.

Develops listening skills

S22: It ensured development of people's listening skills.

Develops interpretation skills 


\section{S2: I think it will contribute to the individual questioning and interpreting other points in their social life.}

Develops comprehension skills

S11: It ensures better understanding of the topic.

\section{Discussion}

After the implementation of the cooperative learning method of academic controversy in social studies teaching lesson, opinions were received from pre-service classroom teachers in this study and participants stated advantages and disadvantages of the method along with recommendations to develop the method. The majority of participant opinions support the results from other research with the topic of the academic controversy method.

The positive effect of the method on empathy, listening and conflict-resolution skills was included in the study by Sarı (2005). The opinion of participants that academic controversy will develop speaking, self-expression and communication skills is supported by studies by Tüzemen and Kardaş (2017) and Kardaş (2015). Like many student-centered methods, participants found academic controversy fun. It led to effective participation of students along with increased self-confidence. The method is student centered as students must access resources themselves as much as possible; in other words, it directs research. These results overlap with the study by Güven (2007). The positive effects of the method on features like acquirements about respect for difference, gaining different perspectives, and multiple perspectives mentioned by participants and the empathy skill mentioned in the study by Sar1 (2005) were expressed by participants in studies by Bruen et al. (2016), Khourey-Bowers (2006) and Monhard and Monhard (2000). Additionally, participants' views that the academic controversy method develops critical skills was supported by participant statements from research by Bruen et al. (2016); about problem-solving skill development in Göğebakan-Yıldız (2015) and Pedersen (1990); about giving democracy education in Khourey-Bowers (2006); and about awareness of responsibility, attitudes to self-learning by the student; in other words design of academic self in Monhard and Monhard (2000).

Some pre-service teachers participating in the research stated they experienced incompatibility between defending opposite views within the group and the compromise stage of finding a common path. Participants in studies by Bruen et al. (2016) and Pederson (1990) reported contrary views stating that students developed in relation to the topic of reaching consensus in academic studies.

Criticisms about nearly all cooperative methods were directed toward academic controversy by participants in this study. Participant statements about the method not being suitable for all levels were reflected in the study by Güven (2007). Statements that it is not suitable for every lesson and topic, is noisy, causes conflict within groups, that group work may easily deviate from the topic and that conflict management and class management is difficult in lessons using this method were included in the study by Monhard and Monhard (2000). The difficulty of applying the method in crowded classes and that duration was insufficient as it took a lot of time are in line with participant statements in research by Bruen et al. (2016).

The results of this study are consistent with results from similar studies in the relevant literature showing that the positive and negative aspects of the academic controversy method display similar features to other cooperative methods, with participants reporting similar effects. Pre-service classroom teachers drew attention to difficulties with implementation, but found the academic controversy method was an effective and beneficial method that could be applied in future classes.

Similar studies to this study may be completed to obtain student and teacher opinions about the academic controversy method or other methods in social science lessons in middle education.

\section{Acknowledgement}

This study was presented as oral presentation at the $8^{\text {th }}$ International Social and Educational Sciences Research Congress in Çorum, Turkey 22-23 August 2020.

\section{References}

Beilby, J. P. (1997). The construction of students' knowledge of ecological concepts through the use of structured controversy compared to individual study. (Unpublished doctoral dissertation), University of Minnesota.

Bruen, J., Crosbie, V., Kelly, N., Loftus, M., Maillot, A., McGillicuddy, Á., \& Pechenart, J. (2016). Teaching controversial topics in the humanities and social sciences in Ireland: Using structured academic controversy to develop multi-perspectivity in the learner. JSSE-Journal of Social Science Education, 15(3), 18-25.

Büyüköztürk, Ş., Kılıç-Çakmak, E., Akgün, Ö. E., Karadeniz, Ş., \& Demirel, F. (2012). Bilimsel araştırma 
yöntemleri (Geliştirilmiş 11. bask1). Ankara: Pegem Akademi. https://doi.org/10.14527/9789944919289

Genç, M., \& Şahin, F. (2015). The Effects of Cooperative Learning on Attitude and Achievement. Necatibey Faculty of Education Electronic Journal of Science \& Mathematics Education, 9(1), 375-396.

Göğebakan-Yıldız, D. (2015). Sosyal Bilgiler Öğretiminde Kullanılan Akademik Çelişki ve Birleştirme II Tekniklerinin Öğrenme Ürünlerine Etkisi. Celal Bayar Üniversitesi Sosyal Bilimler Dergisi, 13(4), 311-329. https://doi.org/10.18026/cbusos.33357

Güven, T. (2007). Akademik çelişki tekniğinin öğrencilerin coğrafya dersindeki başarı ile güdü üzerindeki etkileri (Yayınlanmamış yüksek lisans tezi) Gazi Üniversitesi, Eğitim Bilimleri Enstitüsü, Ankara. https://doi.org/10.1501/egifak_0000001322

Johnson, D. W., \& Johnson, R. T. (1991). Learning together and alone: Cooperative, competitive and individualistic learning (3rd ed.). Needham Heights, MA: Allyn and Bacon.

Johnson, D. W., \& Johnson, R. T. (1994). Learning together and alone: cooperative, competitive, and individualistic learning (4th ed.). Needham Heights, MA: Allyn and Bacon.

Johnson, D. W., Johnson, R. T., \& Holubec, E. J. (1986). Circles of learning: Cooperation in the classroom (rev. ed.). Edina, MN: Interaction Book Co.

Johnson, D. W., Johnson, R. T., \& Holubec, E. J. (1994). Cooperative learning in the classroom. Alexandria, VA: Association for Supervision and Curriculum Development.

Johnson, D. W., Johnson, R. T., \& Smith, K. A. (1991). Cooperative learning: Increasing college faculty instructional productivity (ASHE-ERIC Higher Education Report No. 4.) Washington, DC: School of Education and Human Development, George Washington University.

Johnson, R. T., \& Johnson, D. W. (1979). Type of task, and student achievement and attitudes in interpersonal cooperation, competition, and individualization. Journal of Social Psychology, 108, 37-48. https://doi.org/10.1080/00224545.1979.9711959

Kardaş, M. N. (2015). The effect of academic controversy technique on Turkish teachers candidates success to effective speaking skills and its relation with some variables (gender, multilingualism). Educational Research and Reviews, 10(7), 870-878. https://doi.org/10.5897/err2015.2086

Keçeci, G. (2017). Akademik çelişki tekniğinin fen bilgisi öğretmen adaylarının biyoteknoloji bilgi seviyelerine etkisi. International Journal of Eurasia Social Sciences, 8(30), 2171-2182. https://doi.org/10.17719/jisr.20164622625

Khourey-Bowers, C. (2006). Structured academic controversy: A peaceful approach to controversial issues. The American Biology Teacher, 68(5). https://doi.org/10.1894/0038-4909(2006)68[e43:SACAPA]2.0.CO;2

Kırbağ-Zengin, F., Alan, B., \& Keçeci, G. (2016). Akademik çelişki tekniğinin fen bilgisi öğretmen adaylarının klonlama kavramsal anlama seviyelerine ve fen öz yeterliklerine etkisi. Uluslararası Sosyal Araştırmalar Dergisi, 9(46), 1307-9581. https://doi.org/10.17719/jisr.20164622625

Monhardt, R. M., \& Monhardt, L. C. (2000). The use of academic controversy in elementary science methods classes. Bulletin of Science, Technology \& Society, 20(6), 445-451. https://doi.org/10.1177/027046760002000603

Olsen, R. E., \& Kagan, S. (1992). About cooperative learning. In C. Kessler (Ed.), Cooperative language learning: A teacher's resource book (pp. 1-30). Englewood Cliffs, NJ: Prentice Hall. https://doi.org/10.1177/003368829402500109

Pedersen, J. E. (1990). The effects of science, technology and societal issues, implemented as a cooperative controversy, on attitudes toward science, anxiety toward science, problem-solving perceptions and achievement in secondary science (Unpublished doctoral dissertation). University of Nebraska, Lincoln.

Pederson, C. J. (1990). A comparison of structured controversy with lecture in nursing education (Unpublished doctoral dissertation). University of Minnesota.

Santicola, C. F. (2015). Academic controversy in macroeconomics: An active and collaborative method to increase student learning. American Journal of Business Education (AJBE), 8(3), 177-184. https://doi.org/10.19030 /ajbe.v8i3.9279

Sarı, S. (2005). İlköğretim 5. sınıf öğrencilerine çatışma çözümü becerilerinin kazandırılmasında, akademik çelişki değer çizgisi ve güdümlü tartışma yöntemlerinin etkisi (Yayınlanmamış yüksek lisans tezi) Çukurova 
Üniversitesi Sosyal Bilimler Enstitüsü, Adana.

Tüzemen, T., \& Kardaş, M. N. (2017). Akademik çelişki tekniğinin 6. sınıf öğrencilerinin Türkçe konuşma becerilerine etkisi ve bazı değişkenlerle ilişkisi. Yüzüncü Yll Üniversitesi Eğitim Fakültesi Dergisi, 14(1), 581-610. https://doi.org/10.23891/efdyyu.2017.23

Yıldırım, A., \& Şimşek, H. (2011). Sosyal bilimlerde araştırma yöntemleri. Ankara.

\section{Copyrights}

Copyright for this article is retained by the author(s), with first publication rights granted to the journal.

This is an open-access article distributed under the terms and conditions of the Creative Commons Attribution license (http://creativecommons.org/licenses/by/3.0/). 